University of Michigan Law School University of Michigan Law School Scholarship Repository

2015

\title{
Reflections on Comity in the Law of American Federalism
}

Gil Seinfeld

University of Michigan Law School, gsein@umich.edu

Available at: https://repository.law.umich.edu/articles/1484

Follow this and additional works at: https://repository.law.umich.edu/articles

Part of the Constitutional Law Commons, Jurisprudence Commons, Public Law and Legal Theory Commons, and the Supreme Court of the United States Commons

\section{Recommended Citation}

Seinfeld, Gil. "Reflections on Comity in the Law of American Federalism." Notre Dame L. Rev. 90, no. 3 (2015): 1309-43.

This Article is brought to you for free and open access by the Faculty Scholarship at University of Michigan Law School Scholarship Repository. It has been accepted for inclusion in Articles by an authorized administrator of University of Michigan Law School Scholarship Repository. For more information, please contact mlaw.repository@umich.edu. 


\title{
REFLECTIONS ON COMITY IN THE LAW OF
}

\author{
AMERICAN FEDERALISM
}

\author{
Gil Seinfeld*
}

\begin{abstract}
Comity is a nebulous concept familiar to us from the law of international relations. Roughly speaking, it describes a set of reciprocal norms among nations that call for one state to recognize, and sometimes defer to, the laws, judgments, or interests of another. Comity also features prominently in the law of American federalism, but in that context, it operates within limits that have received almost no attention from scholarly commentators. Specifically, although courts routinely describe duties that run from one state to another, or from the federal government to the states, as exercises in comity, they almost never rely on the term to describe or explain duties that run from the states to the federal government. The goal of this Article is to document and account for this pattern in the law of federalism. I will explore a variety of explanations for the manner in which comity floats in and out of the caselaw, including the possibility that the terminological pattern tells us something fundamental about the meaning and limits of state sovereignty in the context of our federal system.
\end{abstract}

\section{INTRODUCTION}

Comity is a nebulous concept familiar to us from the law of international relations. Roughly speaking, it describes a set of reciprocal norms among nations that call for one state to recognize, and sometimes defer to, the laws, judgments, or interests of another. Comity is a regime of intergovernmental courtesy, and it is principally motivated by a desire to preserve and promote harmony among nations.

Comity also features prominently in the law of American federalism, but in that context, it operates within limits that have received almost no attention from scholarly commentators. Thus, courts routinely describe duties that run from one state to another as exercises in comity, and they do the same with respect to duties that run from the federal government to the

(C) 2015 Gil Seinfeld. Individuals and nonprofit institutions may reproduce and distribute copies of this Article in any format at or below cost, for educational purposes, so long as each copy identifies the author, provides a citation to the Notre Dame Law Review, and includes this provision in the copyright notice.

* Professor of Law, University of Michigan Law School. I am grateful to Allan Erbsen, Don Herzog, Leah Litman, Julian Mortenson, and Richard Primus for reading and commenting on earlier drafts. Thanks also to Nick Bagley, Debra Chopp, Monica Hakimi, and Scott Hershovitz for helpful discussions about this Article. Sommer Engels and Steph Goldfarb provided exceptional research assistance. 
states; but they almost never rely on the term to describe duties that run from the states to the national government. This is so despite the fact that cases fitting into this last category establish rules of behavior that bear important hallmarks of comity-oriented legal regimes.

The principal goal of this Article is to document this pattern in the law of federalism and to consider what we might learn from it. The Article assesses why, in the context of our federal system, some instances of intergovernmental courtesy and deference are characterized as exercises in comity, while others are not. And it focuses, in particular, on what it is about the relationship between the states and the federal government that might make comity an unattractive framework for understanding the former's obligations to the latter.

The strong temptation is to assume that the explanation lies in the fact of federal supremacy. It is to attribute the absence of comity talk from cases involving states' duties to the federal government to the fact that the federal government is a superior sovereign while the states are subordinates, and to the notion that comity is-at least in the familiar, international law paradigm - a framework for the relationships among political equals. But things are not so simple as that, for the cases make clear that political equality is in fact not a prerequisite to the establishment of comity-based norms among sovereigns. (As we'll see, hordes of cases characterize obligations that run from the federal government to the states as exercises in comity.) ${ }^{1}$ Political equality, it would seem, is a familiar feature of comity-oriented relationships, not a necessary one.

It is possible, though, that supremacy affects the availability of comity in a different way. Specifically, it may be the case that comity simply cannot "travel up"-that norms of comity can shape the relationships among political equals, and can guide the behavior of a superior sovereign in its dealings with a subordinate, but cannot set the terms of a subordinate's conduct toward a superior. If that's right, then the pattern that emerges from these bodies of caselaw is entirely predictable.

But if this is the best way to understand the caselaw, then there is more at stake in these decisions than appears at first glance. For the cases, when examined through this lens, become sources of insight into the basic mechanics of our federal system-into the precise nature of state sovereignty and federal supremacy. Even conceding-as any observer must-that the national government is the senior partner in our federal system, ${ }^{2}$ it is hardly necessary that the balance between national supremacy and state sovereignty entail asymmetric access to comity. We might say, instead, that when the Framers "split the atom of sovereignty," 3 they created a scheme wherein comity remains available to the states in their dealings with the nation, the fact of

1 See infra Section II.C.

2 See U.S. Const. art. VI.

3 U.S. Term Limits, Inc. v. Thornton, 514 U.S. 779, 838 (1995) (Kennedy, J., concurring). Just how much atom-splitting went into the fashioning of our federal system is subject to debate. See Alison L. Lacroix, The Ideological Origins of American Federalism 
federal supremacy notwithstanding. We might contend, in the same vein, that because the subordinate governments in the American federal system enjoy the status of bona fide sovereigns, duties that run from those subordinates to the supreme national government do not travel "up" in the relevant sense and so do not render comity inapposite. Yet the cases consistently eschew claims of this sort and refuse to rely on comity to explain states' duties to the federal government. ${ }^{4}$ In so doing, they signal something about the robustness of state sovereignty in the context of the American federal system. And what they signal-that state sovereignty is not so potent as to enable states even to pretend at comity when dealing with the federal governmentis difficult to square with a decades-long trend in the law of American federalism toward a more muscular conception of state sovereignty.

My analysis proceeds in three parts. Part I provides a brief description of how comity is conventionally understood and of the paradigm cases in which it takes hold. Part II surveys cases involving the three basic species of intergovernmental duty in our federal system-state-to-state, state-to-federal, and federal-to-state-and shows that the concept of comity features prominently in the interstate relations cases and the cases involving duties that run from the federal government to the states, but is virtually absent from cases involving duties that run from the states to the federal government.

Part III takes up the question of what we might learn from the terminological pattern in the caselaw. It explores three hypotheses. First, I consider the possibility that courts' abandonment of comity in the key subset of cases is simply an error (or, perhaps, a meaningless oversight). This account proceeds from the premise that, given states' status as bona fide sovereigns in our federal system, comity is a perfectly appropriate framework for understanding their obligations to the federal government. If judges typically fail to see the point, the argument goes, it is because they read too much into the fact of national supremacy and too little into the meaning of state sovereignty.

Second, I take up an argument that approaches the problem from the opposite direction. That is, instead of relying on assumptions about state sovereignty to shape our intuitions about where comity does and does not belong, I inquire whether courts' selective reliance on comity in these decisions might teach us something fundamental about the nature of state sovereignty in the context of the American federal system. It is telling, I will argue, that judges apparently cannot bring themselves (or it simply does not occur to them) to characterize states' obligations to the federal government as exercises in comity. For this lends support to the intriguing notion that, notwithstanding the insistent claims in a battery of modern federalism decisions, judges generally understand states to enjoy something less than the full status and dignity typically associated with sovereignty.

(2010) (exploring antecedents to, and conceptual foundations of, the system of federalism outlined in the U.S. Constitution).

4 See infra Section II.B. 
Finally, I consider the possibility that federal courts' selective reliance on comity across these bodies of caselaw tells us more about the dynamics of membership and union than it does about state sovereignty or national supremacy. Here I focus on the fact that, in the ordinary case, comity helps to guide the interactions among wholly distinct nations. If comity does not accurately describe the nature of states' obligations to the federal government, perhaps it's because states lack the political separateness from the nation that is necessary to enable comity. ${ }^{5}$ Seen in this light, the cases explored here signal something important about the extent to which individual states and the nation are bound up with one another under our constitutional system.

\section{An Introductory Note About Comity}

Before delving into the caselaw, a preliminary word about comity is in order. The term "comity," as noted already, describes a nebulous set of norms familiar from the law of international relations. ${ }^{6}$ In the main, these norms relate to the respect a government institution (often a court) affords to the laws, judgments, and interests of other nations. One widely quoted Supreme Court decision defines comity as "the recognition which one nation allows within its territory to the legislative, executive or judicial acts of another nation."7 Another explains that "[c]omity refers to the spirit of cooperation in which a domestic tribunal approaches the resolution of cases touching the laws and interests of other sovereign states." 8 As the phrase "spirit of cooperation" suggests, the term is closely bound up with notions of voluntariness, reciprocity, and courtesy. Thus, courts and commentators often highlight the fact that a particular decision is governed by "mere" principles of comity, as opposed to being strictly compelled by domestic or international law. ${ }^{9}$ And, in deciding whether to defer to foreign judgments, laws,

5 Of course this raises the question why the point does not cut both ways, i.e., given that the states and the nation are not wholly separate from one another, why is it plausible to say (as the cases do) that federal deference to state interests qualifies as an exercise in comity? I address this question in Section III.C.

6 "Nebulous" is, perhaps, an understatement. See, e.g., Joel R. Paul, Comity in International Law, 32 HARV. INT'L L.J. 1, 4 (1991) (“[D]espite ubiquitous invocation of the doctrine of comity, its meaning is surprisingly elusive."); James C. Rehnquist, Taking Comity Seriously: How to Neutralize the Abstention Doctrine, 46 StAN. L. REv. 1049, 1066-67 (1994) ("The term [comity] is a toothless abstraction, not a rule, invoked in an infinite variety of contexts to justify one governmental body's deference to another. Comity has never had any precise meaning . ..." (footnote omitted)).

7 Hilton v. Guyot, 159 U.S. 113, 164 (1895).

8 Société Nationale Industrielle Aérospatiale v. District Court, 482 U.S. 522, 543 n.27 (1987); see also Black's LaW Dictionary 284 (Bryan A. Garner ed., 8th ed. 2004) (defining "comity" as "[a] practice among political entities (as nations, states, or courts of different jurisdictions), involving esp. mutual recognition of legislative, executive, and judicial acts").

9 See, e.g., Medellin v. Dretke, 544 U.S. 660, 670 (2005) (Ginsburg, J., concurring) ("It is the long-recognized general rule that, when a judgment binds or is respected as a matter 
or interests, courts often focus on whether the foreign nation in question would do the same in the mirror-image case. ${ }^{10}$ Finally, the term is often used interchangeably with "courtesy," and is thus something of a catchall for governmental conduct that is generally respectful of foreign interests and cooperative in nature. ${ }^{11}$

It is important to acknowledge that, in the interstate relations cases and the cases involving duties that run from the federal government to the states-in which comity is referred to repeatedly and appears to be an important part of how courts understand the constitutional obligations in question-the term is routinely left undefined and underspecified. Thus, courts do not identify a cluster of obligations that are characteristic of relationships governed by comity and then recognize or decline to recognize particular duties by reference to whether they fall under the rubric of "comity," thus understood. Instead, the term appears to be a kind of shorthand deployed by judges in the hope that reliance on a concept that is familiar from one set of intergovernmental relations (those among nations) will give us a better sense of how a different set of intergovernmental relations (those among U.S. states) operates.

At the same time, the cases involving duties that run from the states to the federal government-which, we will see, overwhelmingly eschew refer-

of comity, a 'let's see if we agree' approach is out of order" (emphasis added)); Malcolm N. ShaW, INTERnATIONAL LAW 2 (6th ed. 2008) ("The rules of international law must be distinguished from what is called international comity, or practices such as saluting the flags of foreign warships at sea, which are implemented solely through courtesy and are not regarded as legally binding."); JOSEPH STORY, COMMENTARIES ON THE CONFLiCt OF Laws 35 (Boston, Little, Brown \& Co. 8th ed. 1883) ("'[C]omity of nations' . . . is the most appropriate phrase to express the true foundation and extent of the obligation of the laws of one nation within the territories of another. It is derived altogether from the voluntary consent of the latter...." (footnote omitted)).

10 See, e.g., Hilton, 159 U.S. at 210 ("[T] upon which we are satisfied that the comity of our nation does not require us to give conclusive effect to the judgments of the courts of France; and that ground is, the want of reciprocity, on the part of France, as to the effect to be given to the judgments of this and other foreign countries."); United States v. Day, 700 F.3d 713, 722 (4th Cir. 2012) (noting that a particular course of action "would violate the norm of international comity" and explaining that "if the United States wishes to protect its own citizens from bait-and-switch prosecutions when they are extradited for trial in a foreign nation, so too must it honor the same limitation in the reciprocal situation"). This is not to say that courts always treat reciprocity as a strict prerequisite to affording comity to a foreign nation. As leading authorities have noted, in many circumstances, "courts will presumptively recognize and enforce foreign judgments, even in the absence of reciprocity, as long as the foreign court had jurisdiction, the foreign proceedings were procedurally fair, and enforcement does not offend a fundamental public policy." Curtis A. Bradley \& JaCK L. Goldsmith, Foreign Relations Law 134 (4th ed. 2011).

11 See, e.g., Société Nationale, 482 U.S. at 543 n.27; Carbo v. United States, 364 U.S. 611, 621 (1961); Mahon v. Justice, 127 U.S. 700, 706 (1888). The close association between comity and courtesy persists despite the Supreme Court having stated, in Hilton v. Guyot, that "'[c]omity,' in the legal sense, is neither a matter of absolute obligation, on the one hand, nor of mere courtesy and good will, upon the other." 159 U.S. at 163-64. 
ence to comity-sometimes recognize constitutional duties very much like those that take hold where comity is generally understood to be the governing norm. ${ }^{12}$ And it is tempting to conclude that comity is in play in those cases despite judges' failure to say so explicitly. For these reasons, caution is in order before drawing any sharp-edged conclusions from the fact that this particular term pops up often in some contexts but is largely absent from others. It is conceivable that the pattern I observe in the cases is not a pattern at all but is, instead, a meaningless, multifront exercise in terminological sloppiness.

But I don't think that's the most sensible way to understand these materials. It seems shortsighted to dismiss the terminological pattern in the caselaw as error ${ }^{13}$ or accident when, as we'll see, the cases that fit the pattern are so numerous and the pattern is so pronounced. Moreover, it doesn't matter, ultimately, whether some court ought not to have used the term "comity" in a particular interstate relations case or could have referred to comity in some case involving states' duties to the national government without doing violence to the term. (Indeed, the latter possibility is vital to this Article's central thesis.) What matters is that these instances of apparent sloppiness and missed opportunity are distributed systematically-that courts are consistently attracted to the term "comity" in some contexts, while consistently avoiding it in others. For even if we think courts' reliance (or nonreliance) on the term is mistaken from time to time, it is worth considering why the mistakes in question play out in precisely the way they do.

\section{Comity in the LaW of American Federalism}

\section{A. Interstate Relations}

In this Section, I examine cases from the law of interstate relations in an effort to make two modest points. First, the law of horizontal federalism is centrally concerned with binding the states into a closer political union. The key rules, in other words, are designed to prevent actions that might trigger or exacerbate interstate hostility and to help forge and preserve among citizens a sense of identification with a political community that is national in scope. Second, the law endeavors to advance the cause of union through (among other things) a regime of comity-constitutionally mandated mutual recognition and respect.

The claims I make here are not controversial, ${ }^{14}$ and I don't want to spend more time on them than is necessary. But it is worth providing at least

12 See infra Section II.B.

13 I will have more to say in Section III.A about the possibility that courts' failure to rely on comity to explain states' duties to the federal government is essentially an error.

14 Professor Erbsen has argued that "comity rules generally do not exist" in the law of horizontal federalism. Allan Erbsen, Horizontal Federalism, 93 MinN. L. Rev. 493, 568 (2008). But he and I are talking about two different (and compatible) things. Professor Erbsen's emphasis is on the fact that the law generally does not contain rules directing courts to engage in case-by-case interest balancing or weighing of systemic concerns that 
some detail along this dimension because it will help to sharpen the contrast I draw later between these interstate relations cases and cases involving obligations that run from the states to the federal government. Those cases, too, are best understood by reference to the constitutional interest in union and yet, as we will see, they afford comity virtually no attention.

\section{Privileges and Immunities}

Article IV, Section 2, Clause 1 of the U.S. Constitution provides that "[t] he Citizens of each State shall be entitled to all Privileges and Immunities of Citizens in the several States."15 Roughly speaking, the Clause prohibits states from treating citizens of other states too shabbily. Over the years, there has been debate about the Clause on both a micro and a macro level, which is to say that, in addition to run-of-the-mill, case-specific disputes about the application of the Clause to particular sets of facts, ${ }^{16}$ there has been running disagreement as to what kinds of shabby treatment, generally speaking, are covered by the Clause. ${ }^{17}$

But even as there has been debate as to the reach of the Privileges and Immunities Clause, there has been virtually no dispute as to the core purpose the Clause is designed to serve. As the Supreme Court has explained, the Privileges and Immunities Clause was intended to assure "the vitality of the Nation as a single entity" 18 and "to help fuse into one Nation a collection of independent, sovereign States." 19 In thinking about this constitutional value, it is worthwhile to recall that, at the time of the Founding-and the experience of the Revolutionary War and under the Articles of Confederation notwithstanding ${ }^{20}$ - state-level political identity loomed large for citizens of the

might lead one state to yield to the weightier interests of another. These means of exhibiting comity, in other words, do not appear to be the mechanism through which the particular rules do their work. My focus is on the fact that significant swaths of the law of horizontal federalism are animated by a desire to preserve and promote interstate harmony, and that the relevant doctrines do their work by commanding states to respect the laws, policies, and interests of other states. Erbsen's position is fully consistent with the notion that comity is, in fact, doing work in the law of horizontal federalism by motivating the establishment of certain norms of intergovernmental conduct.

15 U.S. Const. art. IV, § 2, cl.1.

16 See, e.g., Supreme Court v. Piper, 470 U.S. 274, 289-90 (1985) (Rehnquist, J., dissenting) (disputing the majority's conclusion that New Hampshire lacked constitutionally adequate justification for limiting bar admission to state residents).

17 Compare Baldwin v. Fish \& Game Comm'n, 436 U.S. 371, 387 (1978) (holding that the Clause prohibits discrimination against nonresidents only with respect to certain "basic and essential activities"), with id. at 395-402 (Brennan, J., dissenting) (criticizing the majority for reviving a "fundamental rights" or "natural rights" approach to the Privileges and Immunities Clause, and insisting that the Clause prohibits unjustified discrimination against out-of-staters without regard to the fundamentality of the underlying right).

18 Id. at 383 (majority opinion).

19 Toomer v. Witsell, 334 U.S. 385, 395 (1948).

20 The Fourth Article of Confederation reflected sensitivity to the hazards of states treating one another's citizens as aliens. It provided: “The better to secure and perpetuate mutual friendship and intercourse among the people of the different states in this union, 
nascent union, and so citizens of one state might have regarded citizens of another as more alien than political kin. The Privileges and Immunities Clause responds to this difficulty, in part, by directing the states to "treat residents and nonresidents without unnecessary distinctions," 21 and, more generally, to purge "the disabilities of alienage" 22 from the realm of interstate relations (or, at least, restrict them to a relatively trivial sphere).$^{23}$

The Clause has most often been deployed to strike down state laws that make it more costly for out-of-staters than in-staters to pursue a common calling. Thus, the Supreme Court has relied on the Privileges and Immunities Clause to invalidate: a South Carolina scheme under which out-of-state commercial fishers were charged 100 times as much as in-staters for shrimp fishing licenses; ${ }^{24}$ New Hampshire laws pursuant to which nonresidents' New Hampshire income was taxed, while residents' out-of-state income was not; ${ }^{25}$ and a New Hampshire law restricting bar admission to resident attorneys. ${ }^{26}$

The Clause has also intermittently been treated as the textual hook for the constitutional constraints on laws inhibiting the right to travel. Thus, in Doe v. Bolton, the Court looked to the Privileges and Immunities Clause to justify invalidating a Georgia law that prohibited nonresidents from obtaining an abortion in the state. ${ }^{27}$ And in a concurring opinion in Zobel $v$. Williams, Justice O'Connor explained that Alaska's scheme for distributing income derived from its natural resources-a scheme based on duration of residence in the state- "conflict[ed] with the constitutional purpose of maintaining a Union rather than a mere league of States" and infringed on the constitutional right to travel, which she located squarely in the Privileges and Immunities Clause. ${ }^{28}$ In Saenz $v$. Roe, finally, the Court explained that the

the free inhabitants of each of these states... shall be entitled to all privileges and immunities of free citizens in the several states." Articles of Confederation of 1781, art. IV, para. 1. The evolution of the rules governing states' treatment of one another's citizens from the colonial period to the Founding is described in David S. Bogen, The Privileges and Immunities Clause of Article IV, 37 CASE W. RES. L. REv. 794 (1987). Bogen highlights the destabilizing effect of independence on the relevant rules, noting that "[i]ndependence broke the [colonists'] link with the King and undercut the requirement that persons from other colonies be treated as common subjects, not aliens." Id. at 817. "[T]he privileges and immunities clause of the Articles of Confederation," he explains, "grew out of the need to restore the common nationality and intercolonial rights that existed before independence," and to prevent states from "discriminat[ing] freely against people from other states." Id.

21 Baldwin, 436 U.S. at 387.

22 Paul v. Virginia, 75 U.S. (8 Wall.) 168, 180 (1868).

23 Baldwin, 436 U.S. at 388 (noting, in the course of upholding a discriminatory scheme for the distribution of elk hunting licenses, that "[e]quality in access to Montana elk is not basic to the maintenance or well-being of the Union").

24 Toomer, 334 U.S. at 389-90.

25 Austin v. New Hampshire, 420 U.S. 656, 666 (1975).

26 Supreme Court v. Piper, 470 U.S. 274, 288 (1985).

27410 U.S. 179, 200 (1973).

28457 U.S. 55, 71, 73, 74 (1982) (O'Connor, J., concurring) (internal quotation marks omitted); see also United States v. Guest, 383 U.S. 745, 767 (1966) (Harlan, J., concurring 
right to travel has three components and that the second of these-"the right to be treated as a welcome visitor rather than an unfriendly alien when temporarily present in [another] State"-is expressly protected by Article IV's Privileges and Immunities Clause. ${ }^{29}$

Crucially, for our purposes, the Supreme Court has repeatedly framed the obligations triggered by the Privileges and Immunities Clause as obligations of comity. The discussion in Austin v. New Hampshire has proven particularly influential in this respect. There the Court referred to Article IV as "the comity article" of the Constitution, explained that the Privileges and Immunities Clause "establishes a norm of comity" among the states, and held that the taxation scheme under review "[could not] be squared with the underlying policy of comity to which the Privileges and Immunities Clause commits us." 30 The Justices have drawn on these passages repeatedly in subsequent Privileges and Immunities Clause decisions, ${ }^{31}$ and commentators, likewise, routinely characterize the constitutional duties embodied in the Privileges and Immunities Clause as exercises in comity. ${ }^{32}$

Note that judges and scholars describe these core applications of the Privileges and Immunities Clause as exercises in comity despite the fact that the relevant constitutional rules lack certain hallmarks of the family of constraints we associate with comity in the international realm. The rules in question do not call for interstate recognition of judgments or respect for other states' laws. And the relevant obligations are truly obligations-backed

in part and dissenting in part) ("[T] he right to unimpeded interstate travel, regarded as a privilege and immunity of national citizenship, was historically seen as a method of breaking down state provincialism, and facilitating the creation of a true federal union."). The question of where the textual foundations of the right to travel lie has long been contested. See Shapiro v. Thompson, 394 U.S. 618, 630 n.8 (1969). For purposes of the analysis here, it does not ultimately matter whether the Privileges and Immunities Clause serves as the relevant textual hook. What matters is that the right to travel decisions sound in horizontal federalism and in union. And there is little doubt on that score. See id. at 630 (noting that the right to travel is "'fundamental to the concept of our Federal Union'" (quoting Guest, 383 U.S. at 757)); $i d$. (noting that the right to travel is an expression of our being "one people, with one common country" (quoting The Passenger Cases, 48 U.S. (7 How.) 283, 492 (1849) (Taney, C.J., dissenting))).

29526 U.S. 489, 500-01 (1999). The Saenz Court concluded that the third component of the right to travel- "the right of the newly arrived citizen to the same privileges and immunities enjoyed by other citizens of the same State"-is rooted in the Privileges or Immunities Clause of the Fourteenth Amendment. Id. at 502-03. The Court declined to take a position on the textual root of what it labeled the first component of the right to travel-the right to travel across state lines. Id. at 500 .

30 Austin, 420 U.S. at $660,666$.

31 See United Bldg. \& Constr. Trades Council v. Mayor of Camden, 465 U.S. 208, 224-25 (1984) (Blackmun, J., dissenting); Zobel v. Williams, 457 U.S. 55, 80 n.10 (1982) (O'Connor, J., concurring in the judgment); Hicklin v. Orbeck, 437 U.S. 518, 523 (1978); Baldwin v. Fish \& Game Comm'n, 436 U.S. 371, 382 (1978).

32 See, e.g., Seth F. Kreimer, Lines in the Sand: The Importance of Borders in American Federalism, 150 U. PA. L. Rev. 973, 1000 (2002) (referring to the Privileges and Immunities Clause as the Constitution's "Comity Clause"); Ryan C. Williams, Originalism and the Other Desegregation Decision, 99 VA. L. REv. 493, 505-06 (2013) (same). 
by constitutional command; they are not duties that states may voluntarily assume or slough off as they please. The aptness of the term in these horizontal federalism cases, it would seem, is bound up in the mutuality of the relevant obligations and the cooperative spirit that lies at their core. The rules in question are designed to foster long-term, harmonious intergovernmental relations grounded in mutual respect, and so describing them as exercises in comity seems entirely regular.

This matters because it indicates that a body of rules may deviate from the international relations comity paradigm without rendering the term "comity" inapposite. And this, in turn, means that when we turn, in Section II.B, to cases involving duties that run from the states to the federal government, we won't be able to explain away the Court's failure to rely on comity simply by identifying a way in which the substantive contours of the legal obligation in question differ from those that take hold in the international relations context.

\section{Full Faith and Credit}

The Full Faith and Credit Clause is also a union-reinforcing device. As the Supreme Court has explained, the Clause is designed "to act as a nationally unifying force," 33 to "transform [ ] an aggregation of independent, sovereign States into a nation," 34 and "to alter the status of the several states as independent foreign sovereignties . . . [and] make them integral parts of a single nation." ${ }^{35}$ The Clause endeavors to advance these goals through a requirement of "reciprocal recognition" 36 of "the public Acts, Records, and judicial Proceedings of every other State." 37 Most notably, this means that when the courts in State $A$ render a valid judgment, the courts in State $B$ are required to treat it as preclusive. ${ }^{38}$ Relitigation is prohibited, even if the los-

33 Univ. of Tenn. v. Elliott, 478 U.S. 788, 799 (1986) (quoting Thomas v. Wash. Gas Light Co., 448 U.S. 261, 289 (1980) (White, J., concurring)).

34 Sherrer v. Sherrer, 334 U.S. 343, 355 (1948).

35 Milwaukee Cnty. v. M.E. White Co., 296 U.S. 268 , 277 (1935). Commentators sound the same themes when discussing full faith and credit. See, e.g., Robert H. Jackson, Full Faith and Credit-The Lawyer's Clause of the Constitution, 45 Colum. L. REv. 1, 17 (1945) (" $[T]$ he full faith and credit clause ... would guard the new political and economic union against the disintegrating influence of provincialism in jurisprudence . . . ."); Larry Kramer, Same-Sex Marriage, Conflict of Laws, and the Unconstitutional Public Policy Exception, 106 YALE L.J. 1965, 2002 (1997) ("Everyone agrees that requiring full faith and credit is supposed to reduce interstate conflict and foster an attitude of friendly cooperation among the states.").

36 Jackson, supra note 35 , at 17.

37 U.S. ConsT. art. IV, § 1.

38 A judgment rendered by a court that lacks jurisdiction is sometimes subject to collateral attack. See, e.g., Durfee v. Duke, 375 U.S. 106, 110 (1963) (" $[\mathrm{A}]$ judgment of a court in one State is conclusive upon the merits in a court in another State only if the court in the first State had power to pass on the merits-had jurisdiction, that is, to render the judgment."). The Supreme Court has given the Clause real bite only in connection with recognition of judgments. The Clause has been construed to pose virtually no limits on state 
ing party in the original action correctly alleges that the courts in State $A$ committed error. ${ }^{39}$

The caselaw in this area is witness to a fair bit of handwringing about the relationship between comity and full faith and credit. This handwringing is an outgrowth of the fact that "comity," in the classic sense, is not "a matter of absolute obligation," 40 while the duties imposed by the Full Faith and Credit Clause are. ${ }^{41}$ For this reason, courts sometimes describe the obligations of full faith and credit in contradistinction to comity-based norms. ${ }^{42}$

Still, it would be a mistake to conclude that comity is, or is generally thought to be, an inapt descriptor of the constitutional obligation of full faith and credit. Precisely the opposite is true. The elements of cooperation, reciprocity, and courtesy are all present. And the core substantive obligation animated by the Clause-to respect certain formal legal actions by other sovereigns-is the bread and butter of comity on the international stage. ${ }^{43} \mathrm{It}$ should come as no surprise, then, that despite the oft-remarked-upon lack of fit along the voluntariness dimension, courts and commentators routinely describe the Full Faith and Credit Clause as a source of comity-oriented constraints on state autonomy. ${ }^{44}$

courts' authority to choose forum law over the law of another state. See, e.g., Allstate Ins. Co. v. Hague, 449 U.S. 302, 320 (1981) (plurality opinion); Douglas Laycock, Equal Citizens of Equal and Territorial States: The Constitutional Foundations of Choice of Law, 92 Colum. L. REv. 249, 257-58 (1992) (explaining that "the modern Supreme Court has all but abandoned the field" of choice of law and "removed most of the content from the Full Faith and Credit Clause").

39 The classic citation is Fauntleroy $v$. Lum, in which the Justices held that a Mississippi court was obligated to afford full faith and credit to the judgment of a Missouri court, notwithstanding the fact that that judgment was premised on the latter court's erroneous application of Mississippi law. 210 U.S. 230, 237-38 (1908).

40 Hilton v. Guyot, 159 U.S. 113, 163-64 (1895).

41 See infra note 45 . The same could be said with respect to the duties imposed under the Privileges and Immunities Clause, yet the handwringing that characterizes the full faith and credit cases is largely absent from the privileges and immunities discourse. I don't know why this is.

42 See, e.g., Williams v. North Carolina, 325 U.S. 226, 228 (1945) ("[T] he Full Faith and Credit Clause puts the Constitution behind a judgment instead of the too fluid, ill-defined concept of 'comity.' "); Williams v. North Carolina, 317 U.S. 287, 301 (1942) ("These . . considerations emphasize for us the essential function of the full faith and credit clause in substituting a command for the former principles of comity ...."); Adar v. Smith, 639 F.3d 146, 152 (5th Cir. 2011) (" $[\mathrm{T}]$ he purpose of the clause was to replace the international law rule of comity with a constitutional duty of states to honor the laws and judgments of sister states.").

43 See supra text accompanying notes 7-8.

44 See, e.g., Marrese v. Am. Acad. of Orthopaedic Surgeons, 470 U.S. 373, 380 (1985) (explaining that the full faith and credit statute (which was enacted pursuant to authority granted by the Full Faith and Credit Clause) "embodies concerns of comity and federalism"); Broderick v. Rosner, 294 U.S. 629, 643 (1935) (describing the constraints animated by the Full Faith and Credit Clause as "rules of comity"); Arthur March Brown, Comity in the Federal Courts, 28 Harv. L. Rev. 589, 590 (1915) ("In American law the word 'comity,' in addition to its normal use, has been borrowed to express relationships not interna- 
In a way, even cases that fixate on the voluntariness angle-and fret over the aptness of the term "comity" in full faith and credit situations-draw attention to the close connection between comity and full faith and credit. They do so by selecting comity-and not some other norm-as the baseline against which the obligations of full faith and credit are measured. The opinions thus acknowledge that the duties in question look very much like those that characterize relationships governed by comity, and they highlight the fact that one of the sticks from the bundle of traits typically associated with comity is missing.

One feature of the law of full faith and credit merits special attention here because it provides a stark example of courts' selectivity in deploying the term "comity" depending on the precise intergovernmental relationship at issue. Our law establishes a broadly comprehensive regime of full faith and credit, by which I mean that, generally speaking, state courts must respect one another's judgments, federal courts must respect the judgments of state courts, and state courts must do the same with respect to federal court decisions. ${ }^{45}$ We have seen already that one of these duties-that of interstate full faith and credit-is widely understood in comity-based terms. ${ }^{46}$ It is also the case that decisions expounding on federal courts' obligation to

tional. . . But it is not quite the comity of international law. It is a comity exercised under the dominance of the 'full faith and credit' clause of the Constitution .....); Thomas $\mathrm{H}$. Lee, Making Sense of the Eleventh Amendment: International Law and State Sovereignty, 96 Nw. U. L. REv. 1027, 1052 (2002) (explaining that the Clause "formalizes the rule of international comity").

45 The constitutional and statutory foundations for these applications of full faith and credit vary. Thus, the duty of interstate full faith and credit is provided for in both Article IV and the Full Faith and Credit Act, 28 U.S.C. $\$ 1738$ (2012). Federal courts' duty to afford full faith and credit to state court decisions is traceable to that same statute, but not Article IV. See 18B Charles Alan Wright et al., Federal Practice and Procedure $\$ 4469$ (2d ed. 2002) [hereinafter WRIGHT \& MILLER] (explaining that modern cases unanimously advance the view that " $[t]$ he Constitutional clause does not speak directly to the federal courts, and it is only the statute and common law that extend the full-faith-and-credit obligation federal courts"). Finally, although nobody doubts that state courts are required to grant full faith and credit to federal court judgments, see e.g., Watkins v. Resorts Int'l Hotel \& Casino, Inc., 591 A.2d 592, 595-96 (N.J. 1991) (explaining that the rule "is accepted as axiomatic"), the constitutional and statutory sources of this obligation are unclear. See Embry v. Palmer, 107 U.S. 3, 9-10 (1883) (noting that the Full Faith and Credit Clause "does not extend to" the question of whether and when federal court judgments have preclusive effect in state court and explaining that "[t] he power to prescribe what effect shall be given to the judicial proceedings of the courts of the United States is conferred by other provisions of the Constitution, such as those which declare the extent of the judicial power of the United States, which authorize all legislation necessary and proper for executing the powers vested by the Constitution in the government of the United States ... and which declare the supremacy of the authority of the national government within the limits of the Constitution"); see also 18B WRIGHT \& Miller, supra, $\$ 4468$ (explaining that "[i]t would be unthinkable to suggest that state courts should be free to disregard the judgments of federal courts," and noting that "several portions of the Constitution can be invoked" to explain this duty).

46 See supra note 44 and accompanying text. 
respect the judgments of state courts routinely characterize that obligation as an exercise in comity. Thus, the Supreme Court has explained that federal courts' grant of preclusive effect to state court judgments "promote[s] the comity between state and federal courts that has been recognized as a bulwark of the federal system." ${ }^{77}$ And it has emphasized that "[d]epriving state judgments of finality . . would violate basic tenets of comity." 48 A survey of cases from the lower federal courts relating to the preclusive effect of state court judgments turns up scores of similar passages. ${ }^{49}$

In the converse scenario, however-i.e., judicial decisions relating to state courts' obligation to afford preclusive effect to federal court judgments-comity plays a far more peripheral role. It is possible to find decisions that describe state courts' duty to respect federal judgments as an exercise in comity, ${ }^{50}$ but these are relatively few in number, and they make up a small fraction of the preclusion cases involving this particular configuration of courts (i.e., federal court as rendering jurisdiction, state court as recognizing jurisdiction). ${ }^{51}$ Hence, while comity is a staple feature of judicial

47 Allen v. McCurry, 449 U.S. 90, 96 (1980).

48 Kremer v. Chem. Constr. Corp., 456 U.S. 461, 478 (1982); see also, e.g., Parsons Steel, Inc. v. First Ala. Bank, 474 U.S. 518, 523 (1986) (reversing a federal court judgment refusing to afford full faith and credit to a state court decision and explaining that "the majority of the Court of Appeals gave unwarrantedly short shrift to the important values of federalism and comity embodied in the Full Faith and Credit Act"); Migra v. Warren City Sch. Dist. Bd. of Educ., 465 U.S. 75, 84 (1984) (holding that federal courts are obligated, under $\$ 1738$, to afford full faith and credit to state court judgments, and explaining that the statute "reflects a variety of concerns, including notions of comity").

49 See, e.g., Dubuc v. Green Oak Twp., 312 F.3d 736, 744 (6th Cir. 2002) (explaining, in a case involving federal courts' duty to afford preclusive effect to a state court judgment, that one of " $[t]$ he purposes of claim preclusion [is] to . . promote comity between the state and federal courts"); E. Food \& Liquor, Inc. v. United States, 50 F.3d 1405, 1412 (7th Cir. 1995) (rejecting a construction of federal law that would "direct district courts to reexamine final state court judgments, in contravention of principles of comity as well as the statutory mandate to grant full faith and credit to final state court decisions"); James v. Guaranteed Rate, Inc., No. 1:09-cv-673, 2012 WL 3023226, at *4 (S.D. Ohio July 24, 2012) (stating that the full faith and credit statute is designed " $t \mathrm{t}]$ o preserve comity and federalism"); Harris v. N.Y. State Dep't of Health, 202 F. Supp. 2d 143, 160 (S.D.N.Y. 2002) ("[I]nsofar as res judicata and collateral estoppel apply in federal actions to require the courts to accord preclusive effect to prior state adjudications, the mandate derives not from a jurisdictional statute, but from 28 U.S.C. $\$ 1738$ and general comity principles.").

50 See, e.g., Greater Canton Ford Mercury, Inc. v. Ables, 948 So. 2d 417, 425 (Miss. 2007); Mullins v. State, 294 S.W.3d 529, 537 n.3 (Tenn. 2009).

51 I could offer a string cite referencing hordes of cases in which state courts' duty to grant preclusive effect to federal judgments is at issue and in which comity is not mentioned, but that wouldn't quite prove my point. One could produce a long list of cases involving the res judicata effect of state court judgments in which the term "comity" does not appear, but, as we have seen, such a sample would provide a skewed picture of courts" general understanding of comity's relevance to such cases. The key point is that it is easy to find cases involving the preclusive effect of state court judgments that $d o$ describe the relevant obligations as an exercise in comity, while one must strain to find cases that discuss state court duties vis-à-vis federal judgments in similar terms. A series of Westlaw 
accounts of state and federal courts' obligation to respect state court judgments, it is a marginal player when state court duties vis-à-vis federal judgments are at issue. This is so despite the fact that the substantive duties recognized in these three contexts (state-state, federal-state, state-federal) are virtually identical and despite the fact that recognition of judgments lies at the core of comity, classically understood.

\section{Extradition}

The Extradition Clause requires states to return fugitives from justice who are found within their borders to the state from which they fled (upon the request of the executive authority of the latter state) ${ }^{52}$ The relationship between this requirement and national unity is straightforward. Within the boundaries of a single state, we expect local authorities to work together to assure that individuals suspected of criminal activity are brought to justice. Under those conditions, law enforcement officials fly the same flag, so to speak; they are part of the same political community, and so cooperation and coordination are expected.

Things become more complicated when border crossings enter the picture. Members of one political community may endorse (or at least not condemn) conduct that another chooses to criminalize, and this might make the former state reluctant to extradite a fugitive accused of engaging in that conduct while in the latter jurisdiction. Alternatively, the escaped-to state might have an unrelated, or more general, beef with the escaped-from state that renders the former reluctant to aid the latter with the return of fugitives from justice.

The Extradition Clause signals that, for these purposes at least, the several states count as a single political community, and individual states' status as independent sovereigns cannot trump their duties to one another as members of a union. The Court has explained, in this vein, that the Extradition Clause "served important national objectives of a newly developing country striving to foster national unity." 53 And it has emphasized that the "right to request extradition" plays a "fundamental role . . . in binding the individual States into a nation." 54

searches of cases involving state courts' duty to afford preclusive effect to federal court judgments turned up a total of fifteen cases in which the court characterized the relevant duty as an exercise in comity. The universe of reported cases in which this duty is at issue surely runs into the thousands. The incidence of comity talk in cases involving the preclusive effect of state court judgments is considerably greater.

52 U.S. Const. art IV, $\$ 2$, cl. 2.

53 Michigan v. Doran, 439 U.S. 282, 288 (1978); see id. (“[N]ational unity was thought to be served by de-emphasizing state lines for certain purposes, without impinging on essential state autonomy.").

54 Puerto Rico v. Branstad, 483 U.S. 219, 225 (1987); see also, e.g., California v. Superior Court, 482 U.S. 400, 405 (1987) ("The Federal Constitution places certain limits on the sovereign powers of the States, limits that are an essential part of the Framers' concep- 
It should come as no surprise-given that the Clause sometimes requires states to subordinate their policies or interests to the policies or interests of other states - that the duties in question are frequently described as exercises in comity. ${ }^{55}$ Here too, some of the references to comity contrast the mandatory nature of the constitutional directive with the discretionary nature of comity on the international stage. ${ }^{56}$ But again, we should not confuse this point of distinction with the notion that the two things are fundamentally disanalogous. The sounder reading-reflected in the Supreme Court's decision in Michigan v. Doran-is that the Extradition Clause "articulated, in mandatory language, the concept [ ] of comity." 57 In other words, the thing required by the Extradition Clause is a show of comity, and it qualifies as such notwithstanding its mandatory character.

\section{B. States' Duties to the National Government}

In this Section, I turn my attention to cases involving duties that run from the states to the federal government. My goal is to illustrate three things. First, the obligations announced in these cases bear important hallmarks of comity-based legal regimes. Second, although these decisions are typically justified by reference to the interest in national supremacy, they are better understood by reference to the interest in union. ${ }^{58}$ This is important because a union-based understanding of these decisions invites comparison with the union-based constraints on state autonomy surveyed in Section II.A. (For as long as we cling to a supremacy-oriented account of the cases involving state-to-federal duties, such a comparison might seem apples-tooranges.) Finally (and here's where the comparison to the interstate relations cases is of interest), comity is essentially ignored in the cases examined here. ${ }^{59}$

tion of national identity and Union. One such limit is found in Article IV, $\$ 2$, cl. 2, the Extradition Clause ....").

55 See, e.g., Behr v. Ramsey, 230 F.3d 268, 270 (7th Cir. 2000) ("The Extradition Clause ... incorporate[s] the general principles of comity and full faith and credit that appear in Art. IV, § 1."); Barton v. Norrod, 106 F.3d 1289, 1297 (6th Cir. 1997) ("The Court has repeatedly articulated the purpose behind the Extradition Clause of the Constitution as one of comity between states ....").

56 See, e.g., Kentucky v. Dennison, 65 U.S. (24 How.) 66, 100 (1860) (“[T] his was not a compact of peace and comity between separate nations who had no claim on each other for mutual support, but a compact binding them to give aid and assistance to each other in executing their laws, and to support each other in preserving order and law within its confines ....").

57 Doran, 439 U.S. at $287-88$.

58 The analysis in this Section draws on my prior work relating to union's role in the law of vertical federalism. See Gil Seinfeld, The Jurisprudence of Union, 89 Notre Dame L. REv. 1085 (2014).

59 We will see that courts readily turn to comity in vertical federalism cases involving duties that run from the federal government to the states. See infra text accompanying notes 95-97. So the claims I make here are not about vertical federalism cases on the 


\section{The Valid Excuse Doctrine}

The place to begin is with the doctrine of valid excuse, which governs state courts' obligation to entertain federal causes of action. Under this doctrine, a state court may decline jurisdiction over a federal claim only if it has a "valid excuse" for doing so. ${ }^{60}$ To qualify as such, a state jurisdictional rule must be evenhanded in its application to state and federal claims-which is to say that states cannot close their courthouse doors to a federal cause of action while keeping those doors open for state law claims of the same ilk. ${ }^{61}$ The valid excuse doctrine also prohibits state courts from dismissing federal causes of action on jurisdictional grounds except pursuant to a genuine "rule of judicial administration"-which means that states cannot refuse jurisdiction over a federal claim because of disagreement with the policy underlying the federal law in question. ${ }^{62}$

Thus, if a state court dismisses a federal claim because of concerns relating to "power over the person [or] competence over the subject matter," 63 the dismissal will be deemed a bona fide exercise in judicial administration, and no constitutional problem will arise. ${ }^{64}$ However, if a state court with jurisdiction otherwise adequate to the task is prohibited from adjudicating a federal claim because the state thinks the establishment of that claim was just a bad idea, then the applicable rule will be regarded more as one of substance than judicial administration, and the dismissal will be subject to reversal. ${ }^{65}$

The Supreme Court has endeavored to justify these constraints on state jurisdictional autonomy by reference to national supremacy. Thus, Testa $v$. $K a t t$ (which is the mostly widely studied case in this line) explicitly grounds the doctrine in the Supremacy Clause. ${ }^{66}$ And the Court's most recent pro-

whole, but only those cases involving union-based limits on state autonomy. I explore this asymmetry in depth in Part III.

60 The default presumption is that state and federal courts enjoy concurrent jurisdiction over federal claims. See Claflin v. Houseman, 93 U.S. 130, 136-37 (1876).

61 See, e.g., Haywood v. Drown, 556 U.S. 729, 739 (2009); Testa v. Katt, 330 U.S. 386, 394 (1947).

62 Haywood, 556 U.S. at 736-39. For many years, it seemed as if state-federal neutrality alone was sufficient to secure the constitutionality (for Supremacy Clause purposes, at least) of a state court's jurisdiction-based dismissal of a federal cause of action. The decision in Haywood made clear that this is not so. Id. at 739 ("Although the absence of discrimination [against federal claims] is necessary to our finding a state law neutral, it is not sufficient.").

63 Howlett v. Rose, 496 U.S. 356, 381 (1990).

64 Forum non conveniens is the paradigm here. See, e.g., Missouri ex rel. S. Ry. v. Mayfield, 340 U.S. 1, 4-5 (1950) (remanding actions brought under the Federal Employers Liability Act and explaining that it is permissible for a state court to dismiss a federal cause of action on forum non conveniens grounds provided the doctrine is applied evenhandedly to state and federal claims).

65 See Haywood, 556 U.S. at 739-41.

66 Testa, 330 U.S. at 389-91. Valid excuse cases going back to the early twentieth century also signal, albeit more obliquely, that the relevant rules are rooted in Article VI. 
nouncement on the law of valid excuse-the 2009 decision in Haywood $v$. Drown-takes pains to highlight the ways in which state jurisdictional rules might undermine the supremacy of federal law. ${ }^{67}$ But the supremacy-based justifications proffered by the Court are unpersuasive, for the dismissal of a federal cause of action from state court on jurisdictional grounds poses no obstacle to the ultimate vindication of that claim. In the ordinary course of things, dismissal for want of jurisdiction is without prejudice to the plaintiff refiling in some other appropriate tribunal. And it is far from obvious that the supremacy of federal law is threatened by a jurisdictional scheme that does not extinguish any federal claims, but instead reroutes them to some other court. ${ }^{68}$

To be sure, a state jurisdictional law that calls for the ouster of a federal cause of action from state court on grounds of policy disagreement subordinates federal policy to state policy. And this sort of subordination is an awkward fit for a scheme that designates federal law supreme. But the threat to federal supremacy that is posed by state jurisdictional laws of this sort is different in kind from the threat that inheres in state laws that trigger withprejudice dismissal of federal claims from state court. ${ }^{69}$ The latter sort of rule makes nonsense of our commitment to federal supremacy-what does it mean to say that federal law is "supreme" if state laws have the capacity to prevent the enforcement and implementation of federal law? But the same cannot be said for jurisdictional rules like those at issue in the valid excuse cases. Those rules, again, do not impede the ultimate vindication of federal rights, and so they fall well short of rendering claims of federal supremacy incoherent. The question, then, is why the particular breed of supremacy established in Article VI should be understood to prohibit this relatively tame exercise in subordinating federal policy to that of a state. What constitutional value, we might ask, is threatened by state jurisdictional rules that subordinate federal policy to state policy but do not prevent the vindication of any federal claims?

The answer is union. The interest in union, we have seen, is about binding the states into a single, national, political community. And it is under-

These cases lean heavily on the Court's decision in Claflin v. Houseman for support. See, e.g., Mondou v. N.Y., New Haven \& Hartford R.R., 223 U.S. 1, 57-58 (1912) (quoting at length from Claflin v. Houseman, 93 U.S. 130, 136-37 (1876)). That case-which holds that state courts presumptively enjoy concurrent jurisdiction over federal causes of action-is grounded firmly in the Supremacy Clause. Claflin emphasizes that "[ $\mathrm{t}$ ] he laws of the United States are laws in the several States," and that federal and state law "together form one system of jurisprudence, which constitutes the law of the land for the State." Claflin, 93 U.S. at 136-37. The "law of the land" passage is an unmistakable reference to Article VI.

67 Haywood, 556 U.S. at 736, 739, 741 n.8 (contending that state jurisdictional law carries the capacity to "nullify ... federal right[s]," "thwart [their] enforcement," "burden ... a federal cause of action," or "undermine federal law").

68 Justice Thomas emphasized this point in his dissenting opinion in Haywood. Id. at 771-73 (Thomas, J., dissenting).

69 See generally Seinfeld, supra note 58, at 1116-42. 
mined when state courts decline jurisdiction over federal causes of action under circumstances covered by the doctrine of valid excuse. This is easy to see in connection with jurisdictional rules that discriminate against federal claims. Rules of this sort straightforwardly classify federal causes of action as "other." They lump federal claims together with causes of action established by other states and by foreign sovereigns, ${ }^{70}$ and they subject those claims to disfavored treatment precisely because they are not the states' own. It should come as no surprise-in a constitutional system that endeavors in various ways to intensify states' and citizens' sense of identification with the nationthat the Court has deemed this species of jurisdictional discrimination unconstitutional.

Union can also help us to make sense of the constitutional prohibition on state jurisdictional rules that are motivated by disagreement with federal policy. When state courts that are otherwise competent to adjudicate a particular federal claim are disabled from doing so because the state thinks it was a mistake for the federal government to establish the cause of action in the first place, the state thereby dissociates itself from federal law and policy. It classifies the normative commitments underlying federal law as "yours, not ours," and it does so despite the fact that the state and its citizens belong to the political community that generated the law in question. ${ }^{71}$ In this way, the jurisdictional carve-outs prohibited by the doctrine of valid excuse rest on a thin conception of membership in our national political community. The doctrine itself, meanwhile, is best understood as an effort to rein in state laws that send the wrong message about what union means in the context of the American federal system. ${ }^{72}$

What is particularly noteworthy about this body of decisions, for present purposes, is that comity is ignored almost entirely. ${ }^{73}$ It is worth pausing for a

70 See, e.g., Testa, 330 U.S. at 388-89 (discussing the Rhode Island court's dismissal of a federal cause of action on the ground that it "need not enforce the penal laws of a government which is foreign in the international sense," and explaining "we cannot accept the basic premise on which the Rhode Island Supreme Court held that it has no more obligation to enforce a valid penal law of the United States than it has to enforce a penal law of another state or a foreign country").

71 See id. at 393 (reversing the dismissal of a federal cause of action from state court and emphasizing that "the policy of the federal Act is the prevailing policy in every state"); Mondou, 223 U.S. at 57 (noting that when Congress enacts federal law, "it [speaks] for all the people and all the States, and thereby establishe[s] a policy for all" and explaining that " $[t]$ hat policy is as much the policy of [a state] as if the act had emanated from its own legislature").

72 See Seinfeld, supra note 58 , at 1088.

73 The only reference to comity in a plausibly relevant decision comes from Kentucky $v$. Dennison, 65 U.S. (24 How.) 66 (1860), where the Court explained that early Congresses "relied with confidence upon the co-operation and support of the States," including with reference to the adjudication of federal causes of action, and "were accustomed to receive it, upon principles of comity, and from a sense of mutual and common interest, where no such duty was imposed by the Constitution." Id. at 108. More than a century later, the Court would dismiss this way of thinking about the relationship between the federal government and the states as an error, see Fed. Energy Regulatory Comm'n v. Mississippi, 456 
moment to consider how comfortably the term would seem to fit. The cases in question direct one sovereign to subordinate its policies or interests to those of another; they endeavor to reduce federal-state friction by reinforcing our status as a single nation; and they even call attention, from time to time, to similarities between the constitutional constraints they announce and other limits on state autonomy that are widely understood as comitybased norms. ${ }^{74}$ For all of these reasons, it would have been entirely natural for the Justices to describe the duties recognized in the valid excuse cases as exercises in comity. Yet they did no such thing. ${ }^{75}$

On its own, the point is hardly earthshaking. These cases do not represent the only time the Justices have failed to deploy a particular term that might have fit snugly into a case or body of decisions. And we cannot always make something of the dog that didn't bark. As we'll see in the sections that follow, however, the valid excuse decisions are part of a broader pattern; and when we consider the cases in the aggregate, the Court's failure to mention comity in connection with the law of valid excuse seems considerably more telling.

U.S. 742, 763 n.28 (1982) (noting that the "analysis cannot survive Testa, which squarely held 'that state courts do not bear the same relation to the United States that they do to foreign countries'" (quoting Testa, 330 U.S. at 389)), though it attributed Dennison's error to confusion about the nature of federal supremacy, rather than union. See id.

74 Howlett v. Rose, 496 U.S. 356 (1990), supplies a particularly clear example. There the Court noted that states cannot evade the duties of mutual respect and recognition imposed by the Full Faith and Credit and Privileges and Immunities Clauses by providing that otherwise competent state tribunals simply lack jurisdiction to enforce the law of another state or to entertain causes of action created by the law of another state. Id. at 381-82. The Court then explained that the Supremacy Clause spawns a similar constraint when it comes to state courts' duty to entertain federal causes of action. Id. at 382-83; see McKnett v. St. Louis \& S.F. Ry, 292 U.S. 230, 233 (1934) (explaining that " $t$ t] he power of a State to determine the limits of the jurisdiction of its courts and the character of the controversies which shall be heard in them is, of course, subject to the restrictions imposed by the Federal Constitution," and then listing the doctrine of valid excuse along with the rules rooted in the Full Faith and Credit and Privileges and Immunities Clauses as examples of these restrictions). Commentators have drawn this parallel as well. See, e.g., Alfred Hill, Substance and Procedure in State FELA Actions-the Converse of the Erie Problem?, 17 Онго ST. L.J. 384, 410 n.159 (1956) ("Just as the states are obliged to give effect to legal rights created by other states, so they are obliged, even without a Congressional directive, to give effect to legal rights created by federal law." (citations omitted)).

75 Nor, for that matter, does the academic commentary on the valid excuse decisions conceptualize the relevant duties in comity-based terms. As noted already, we cannot explain this away by noting that the valid excuse decisions recognize binding limits on state autonomy - that is, truly mandatory burdens-and suggesting that comity, by definition, is the stuff of voluntary recognition of another government's interests. Courts and commentators routinely characterize other union-based constraints on state autonomy in comitybased terms notwithstanding the fact that those constraints are fully binding on the states. See supra text accompanying note 44 . 


\section{Dormant Foreign Affairs Preemption}

The doctrine of dormant foreign affairs preemption provides another example of union doing work in the law of vertical federalism-work that is typically (and mistakenly) assigned to the interest in national supremacyand of the Court declining a ready opportunity to classify the relevant rules as exercises in comity. The key cases are Zschernig v. Miller, ${ }^{76}$ Crosby $v$. National Foreign Trade Council, 77 and American Insurance Association $v$. Garamendi. ${ }^{78}$ In each of these cases, the Court determined that the state law under review interfered with the foreign policy of the United States and was therefore preempted by federal law. ${ }^{79}$ The opinions are littered with expressions of concern about the capacity of the relevant state laws to sabotage federal law and policy and thereby undermine national supremacy. ${ }^{80}$ But supremacy is just not up to the task of justifying the Court's conclusions in these cases. As numerous commentators have explained, the asserted claims of tension between the state laws under review and some identifiable federal policy are, by turns, strained, unprecedented, or transparently weak..$^{81}$ In other words, it takes work (and sometimes it is just not possible) to find a genuine threat to federal supremacy lurking in these cases.

It takes little effort, however, to see that the interest in union is implicated when states enact laws that affect relationships with foreign nations. Justice Stewart put the point clearly in his concurring opinion in Zschernig: "for national purposes," he explained, "embracing our relations with foreign nations, we are but one people, one nation, one power." 82 When a state intervenes in foreign relations, it dismisses this entailment of union; it acts, instead, in a manner characteristic of a nation unfettered by the constraints of political confederation. The Court's aggressive efforts to zone the states out of the realm of foreign affairs owe more to these considerations-politi-

$76 \quad 389$ U.S. 429 (1968).

77530 U.S. 363 (2000).

78539 U.S. 396 (2003).

79 See id. at 401 (explaining that the state law in question "interfere[d] with the National Government's conduct of foreign relations"); Crosby, 530 U.S. at 373 (characterizing the law under review as "an obstacle to the accomplishment of Congress's full objectives under the federal Act"); Zschernig, 389 U.S. at 440 (expressing concern that the state law under review might "impair the effective exercise of the Nation's foreign policy").

80 See supra note 79; see also Garamendi, 539 U.S. at 424-25 (noting that the state law under review "threatens to frustrate the operation of the" President's foreign policy and "is an obstacle to the success of the National Government's chosen [approach]"); Crosby, 530 U.S. at 366, 373 (taking note of state law's capacity to "frustrat[e] federal statutory objectives" and to "undermine[ ] the intended purpose and 'natural effect' of . . . the federal Act"); Zschernig, 389 U.S. at 435, 441 (noting that state law might "disrupt[ ]" U.S. foreign relations, "embarrass[]" the United States, or "adversely affect the power of the central government to deal with [foreign affairs] problems").

81 See Seinfeld, supra note 58, at 1099-1105 (surveying and expanding upon critical commentary).

82 Zschernig, 389 U.S. at 442 (Stewart, J., concurring) (quoting Chae Chan Ping v. United States, 130 U.S. 581, 606 (1889)). 
cal identity and national unity-than to concern for the supremacy of federal law and policy.

Here too, the constraints on state autonomy recognized by the Court might readily have been characterized as requirements of comity. Comityoriented rules often direct a sovereign with a legitimate interest in some regulatory matter to yield to the comparatively greater interests of another. ${ }^{83}$ And they are frequently designed to reduce friction between and among sovereigns by ensuring that they do not step on one another's toes. ${ }^{84}$ The foreign affairs decisions have these features, and yet the cases avoid any suggestion that states' obligation to stand aside in the relevant circumstances has anything to do with comity.

To be clear, my point is neither that the constraints on state autonomy recognized in these foreign affairs cases must be classified as exercises in comity, nor that the Court's failure to appeal to comity in these decisions reflects confusion on the Justices' part. The point is simply that the relevant constraints could have been classified as such-the Court might have stated that when foreign affairs are at stake, considerations of comity require states to cede the regulatory floor to the national government-and no one would have batted an eye. Again, this raises the question of why, if the constraints at issue could be understood in comity-based terms, the Court declined to classify them as such.

\section{Intergovernmental Tax Immunity}

The law of intergovernmental tax immunity provides further evidence of union's role as an active, independent force in the law of vertical federalism ${ }^{85}$ and of the Justices' apparent reluctance to use the term "comity" where state obligations to the federal government are at issue. Generally speaking, the law prohibits states from directly taxing the federal government, but it permits states to tax private parties' income from transactions with the fed-

83 See, e.g., Erbsen, supra note 14, at 561 (noting that a rule of comity requires "that states with capacity to act free from constraint and central control . . y yield . . . to the relatively more significant interests of another state").

84 A good example is the doctrine of Pullman abstention, which directs federal courts to abstain from ruling on the constitutionality of state laws so that state courts can have an opportunity to interpret the law in a manner that avoids constitutional difficulty. R.R. Comm'n v. Pullman Co., 312 U.S. 496, 500-01 (1941). The Pullman rule is routinely characterized as an exercise in comity, see infra note 95 , and in the reduction of intergovernmental friction. Pullman, 312 U.S. at 501 ("These cases reflect a doctrine of abstention appropriate to our federal system whereby the federal courts, 'exercising a wise discretion,' restrain their authority because of 'scrupulous regard for the rightful independence of the state governments' and for the smooth working of the federal judiciary. This use of equitable powers is a contribution of the courts in furthering the harmonious relation between state and federal authority...." (citation omitted)); see also id. at 500 (taking note of the interest in "the avoidance of needless friction with state policies").

85 The survey provided here is not exhaustive. See Seinfeld, supra note 58, at 1114-16 (explaining that the Supreme Court's decision in the voting rights case, Carrington $v$. Rash, 380 U.S. 89 (1965), is best understood in union-based terms). 
eral government so long as the tax "does not discriminate against the United States or those with whom it deals." 86 The doctrine is typically justified by reference to the interest in supremacy. The theory is that if states had the power to tax the federal government directly or had unfettered authority to tax private income from transactions with the federal government, they might seriously undermine federal interests by taxing disfavored federal activities into oblivion. The nondiscrimination requirement is designed to discipline states' exercise of the tax power by rendering the states incapable of burdening the federal government without burdening large numbers of constituents at the same time. With a nondiscrimination rule in place, the argument goes, self-interest will discourage state officials from establishing taxes so onerous as to meaningfully undermine national prerogatives. ${ }^{87}$

In some circumstances, however, the constitutional law of taxation requires more of states than this particular breed of equal treatment. Thus, the Court has twice invalidated state taxation schemes that afforded exemptions to state and local government employees while denying them to federal employees. ${ }^{88}$ The Court did so notwithstanding the fact that (a) the state laws in question lumped federal employees together with literally millions of other state taxpayers (to wit, persons not employed by state and local government), and so (b) the standard supremacy-based rationale for the doctrine would seem to militate in favor of constitutionality. ${ }^{89}$ One would think (and the standard account presumes) that by casting federal employees' lot together with that of the vast majority of state taxpayers, the taxation schemes in question would pose no meaningful threat to national supremacy. Again, the intuition is that state legislators would be unlikely to impose genuinely onerous tax burdens on so many constituents.

Here too, what supremacy cannot explain, union can. For while the assignment of most-favored-nation status to federal employees seems like overkill if the goal is to safeguard national supremacy, it makes perfectly good sense if the goal is to police the conception of union underlying state law. The grant of tax exemptions to government employees is a means of rewarding work that the state deems especially valuable. The tax immunity cases signal that if a state wishes to single out "government work" for preferable treatment, it must value work performed on behalf of the nation no less than it does work performed on behalf of the state. ${ }^{90}$ The point is about

86 South Carolina v. Baker, 485 U.S. 505, 523 (1988).

87 See, e.g., United States v. Cnty. of Fresno, 429 U.S. 452, 463 n.11 (1977) ("A tax on the income of federal employees ... if imposed only on them, could ... destroy the federal function performed by them . . . by causing the Federal Government to pay prohibitively high salaries. This danger would never arise, however, if the tax is also imposed on the income ... of all other residents and voters of the State.").

88 See Barker v. Kansas, 503 U.S. 594, 605 (1992) (invalidating a state law exempting some state and local government employees' benefits from taxation); Davis v. Mich. Dep't of the Treasury, 489 U.S. 803 (1989) (similar).

89 See Barker, 503 U.S. at 596-601; Davis, 489 U.S. at 805-07.

90 See Seinfeld, supra note 58, at 1105-09. 
political identity: the cases admonish states to be mindful of the fact that within our federal system, political identity has a dual character.

The duty at issue in these cases is not quite in comity's wheelhouse to the same extent as, say, the requirements governing state court adjudication of federal claims. (Those rules direct states to recognize and respect the law of another sovereign and, in this way, resemble classic exercises in comity.) But still there is reason to think the term might apply. The tax immunity rule commands a species of intergovernmental courtesy, and it directs one sovereign to subordinate its interests to those of another. Moreover, there is overlap in the justifications offered by the Court for key features of tax immunity doctrine and the justification relied upon to support some of the comityoriented norms familiar to us from the law of horizontal federalism. ${ }^{91}$ Yet, here too, comity plays no role in the caselaw.

If we were to consider the doctrines surveyed above in isolation from one another, comity's absence might seem unremarkable. None establishes rules precisely like, say, the classic comity-based requirement of judgment recognition that we find in the law of international relations and in the law of horizontal federalism. And of course missed terminological opportunities in a case or line of decisions are often accidental and/or path dependent. But when we consider these decisions in the aggregate-and especially in light of the fact that the term comity has been "invoked in an infinite variety of contexts to justify one governmental body's deference to another"92-the Court's failure to turn to comity seems puzzling.

91 Specifically, the Court has emphasized, in connection with both tax immunity doctrine and the Privileges and Immunities Clause, that state laws sometimes burden persons or entities that lack full-throated representation in state government. See McCulloch v. Maryland, 17 U.S. (4 Wheat.) 316, 428 (1819) ("The only security against the abuse of [the power to tax], is found in the structure of the government itself. In imposing a tax the legislature acts upon its constituents. This is in general a sufficient security against erroneous and oppressive taxation. The people of a State, therefore, give to their government a right of taxing themselves and their property ... resting confidently on the interest of the legislator, and on the influence of the constituents over their representative, to guard them against its abuse. But the means employed by the government of the Union have no such security, nor is the right of a State to tax them sustained by the same theory."); see also United Bldg. \& Constr. Trades Council v. Mayor of Camden, 465 U.S. 208, 230 (1984) (Blackmun, J., dissenting) ("The [Privileges and Immunities] Clause has been a necessary limitation on state autonomy not simply because of the self-interest of individual States, but because state parochialism is likely to go unchecked by state political processes when those who are disadvantaged are by definition disenfranchised as well."); Austin v. New Hampshire, 420 U.S. 656, 662 (1975) (" $[N]$ onresidents are not represented in the taxing State's legislative halls."). The Privileges and Immunities Clause cases seem to imagine comity as a norm that might fill a gap of interest consideration that inheres in the structure of political representation. One might easily characterize the tax immunity rules the same way. But the Court doesn't.

92 See Rehnquist, supra note 6, at 1066-67. 
Moreover, once we acknowledge the fact that the constitutional interest in union best explains these aspects of our federalism, comity's absence is more striking still. We have seen that, in the interstate relations context, the interest in union is closely and consistently linked to the adoption of comitybased norms. Yet the vertical federalism decisions, even as they endorse rules that are ultimately motivated by that same interest, offer no suggestion that these rules require a species of intergovernmental comity.

\section{Federal Duties to the States}

Before turning, in Part III, to an analysis of what might explain the terminological pattern documented above, I want to say a quick word about cases involving the third set of intergovernmental duties in our federal system-those that run from the federal government to the states. ${ }^{93}$ The goal here is both to fill out the picture of how comity fits (and doesn't fit) into the law of federalism and to quickly dispose of an explanation that might be offered for comity's absence from the cases surveyed in Section II.B.

It is tempting to presume that the reason courts ignore comity in cases involving state-to-federal duties is that the term can have no application to the relationship between a superior and a subordinate sovereign. Comity, the argument goes, is a characteristic element of the relationships among political equals. Thus, it features prominently in the law of international relations, and it is a staple of the law of horizontal federalism, but it has no place in accounts of the relationship between the federal government and the states, since that relationship is characterized by hierarchy.

The difficulty with this argument is that it runs headlong into literally hundreds of decisions involving federal-state relations that treat comity as a relevant norm. We have seen already that courts routinely characterize federal courts' obligation to afford full faith and credit to state court judgments as an exercise in comity. ${ }^{94}$ And that is but one of many examples. Comity is routinely relied upon to justify requirements that federal courts abstain from adjudicating cases within their jurisdiction so that proceedings at the state

93 Also of interest are the relationships between Native American tribes, on the one hand, and the federal government or the states, on the other. Though I have not undertaken a comprehensive study of comity's role in shaping those relationships, I can report that many state and federal courts have recognized a duty to respect the judgments of tribal courts and have characterized that duty as an exercise in comity. See, e.g., United States v. Shavanaux, 647 F.3d 993, 998 (10th Cir. 2011) ("Courts analyze the recognition of tribal judgment under principles of comity . . . ."); AT\&T Corp. v. Coeur d'Alene Tribe, 295 F.3d 899, 903 (9th Cir. 2002) ("As a general rule, federal courts must recognize and enforce tribal court judgments under principles of comity."); John v. Baker, 982 P.2d 738, 763 (Alaska 1999) (holding that, "as a general rule, [Alaska] courts should respect tribal court decisions under the comity doctrine"); Beltran v. Harrah's Ariz. Corp., 202 P.3d 494, 498 (Ariz. Ct. App. 2008) ("Arizona courts have generally recognized tribal court judgments as a matter of comity.").

94 See supra notes 47-49 and accompanying text. 
level can run their course; 95 it is commonplace for courts to note that constraints on federal habeas corpus review of state criminal convictions are animated by considerations of comity; 96 and it is standard practice for federal courts to list comity among the values that should guide their exercise of supplemental jurisdiction over state law claims. ${ }^{97}$

Of course, these cases are configured differently from those examined in Section II.B-the abstention, habeas, and supplemental jurisdiction cases all involve duties that run from the federal government to the states, and not

95 See, e.g., Younger v. Harris, 401 U.S. 37, 44 (1971) (directing federal courts to abstain from enjoining ongoing state criminal proceedings and explaining that the duty to abstain is rooted in 'the notion of 'comity,' that is, a proper respect for state functions, a recognition of the fact that the entire country is made up of a Union of separate state governments, and a continuance of the belief that the National Government will fare best if the States and their institutions are left free to perform their separate functions in their separate ways"); Harrison v. NAACP, 360 U.S. 167, 176-77 (1959) (explaining that Pullman abstention, which directs federal courts to abstain from adjudicating questions of federal constitutional law when it is possible that a state court's construction of state law might obviate the need to determine the federal question, "is aimed at the avoidance of unnecessary interference by the federal courts with proper and validly administered state concerns," and "serves the policy of comity inherent in the doctrine of abstention"); Ala. Pub. Serv. Comm'n v. S. Ry., 341 U.S. 341, 350 (1951) (explaining that Burford v. Sun Oil Co., 319 U.S. 315 (1943), which requires federal courts to abstain so that complex state administrative processes can run their course, reflects "the usual rule of comity ... [that] govern[s] the exercise of equitable jurisdiction by the [federal courts]"). Scores of cases from the lower federal courts echo these comity-oriented accounts of the abstention doctrines. See, e.g., Nat'l City Mortg. Co. v. Stephen, 647 F.3d 78, 83 (3d Cir. 2011); Johnson v. Collins Entm't Co., 199 F.3d 710, 718-19 (4th Cir. 1999). To be clear, neither the Supreme Court nor the lower federal courts suggest that comity supplies the only justification for these abstention requirements. See, e.g., Younger, 401 U.S. at 44 (noting that longstanding traditions of equity jurisprudence and considerations of federalism militate in favor of abstention); see also note 98 and accompanying text.

The unidirectional character of comity in the context of the relationship between the federal government and the states comes through especially clearly in the abstention cases. In Hicks v. Miranda, in particular, the Court held that the Younger doctrine may bar the grant of injunctive or declaratory relief to a federal court plaintiff if state officials initiate a prosecution against that plaintiff "before ... proceedings of substance on the merits have taken place in . . . federal court." 422 U.S. 332, 349 (1975). Nowhere did the Court suggest that considerations of comity might militate in favor of having the state court defer to the federal court under those conditions. The point is not so much that the Hicks Court should have reached a different conclusion; it is, rather, that the Court did not even entertain the possibility that comity might favor state deference to federal interests.

96 See, e.g., Francis v. Henderson, 425 U.S. 536, 539 (1976) (tightening of procedural default rules motivated by "considerations of comity and concerns for the orderly administration of criminal justice"); Preiser v. Rodriguez, 411 U.S. 475, 491 (1973) (noting that requirements of exhaustion are "rooted in considerations of federal-state comity").

97 See, e.g., City of Chi. v. Int'l Coll. of Surgeons, 522 U.S. 156, 173 (1997) (“[W] hen deciding whether to exercise supplemental jurisdiction, 'a federal court should consider and weigh in each case, and at every stage of the litigation, the values of judicial economy, convenience, fairness, and comity.' (quoting Carnegie-Mellon Univ. v. Cohill, 484 U.S. $343,350(1988)))$. 
vice versa. This distinction merits attention, and I will consider it carefully in Part III. For now, however, it suffices to note that these are all vertical federalism decisions, and still comity features prominently in them. So the facile claim that intergovernmental hierarchy and comity simply cannot mix is inconsistent with the evidence.

To be sure, it is difficult to say how much independent work comity performs in the cases involving duties that run from the federal government to the states, since it conspires with related forces-most notably state sovereignty-to support the Justices' conclusions. ${ }^{98}$ We cannot dismiss out of hand the possibility that the references to comity that we see in these pockets of caselaw are no more than a makeweight-a gesture in the direction of a nebulous norm of intergovernmental conduct that is ultimately inessential to the outcomes in the particular cases and to the general shape of the doctrines they develop. If this is right, perhaps it remains accurate to say that, in the context of our federal system, comity does real work only where interstate relations are at issue.

But I don't think this reasoning follows, or, at least, I don't think it's relevant to the inquiry pursued here. What matters, for our purposes, is the mere fact that courts apparently deem it plausible that comity might make weight (even if nothing more) in the context of federal-state relations. If comity could not possibly help us to understand the relationship between a superior and a subordinate sovereign, then even gesturing in its direction in these cases would seem confused. Yet I doubt that anyone has the instinct to dismiss the turn to comity in, say, the abstention or habeas cases as a kind of category error. ${ }^{99}$ (They might regard it as empty, but not confused.)

98 Younger and the habeas cases, in particular, run the concepts of comity and federalism together. See Younger, 401 U.S. at 44 (explaining that the principles of comity that undergird the abstention requirement are "referred to by many as 'Our Federalism'"); Williams v. Taylor, 529 U.S. 420, 436 (2000) (taking note of "AEDPA's purpose to further the principles of comity, finality, and federalism"). Comity and federalism are closely integrated forces, since comity (at least in the sense relevant here) is something reserved for sovereign entities, and it is thus the fact of states' status as bona fide sovereigns (something established by the particular features of our constitutional federalism) that renders them plausible candidates for a comity-oriented relationship. Thus, to say that the federal courts owe a duty of comity to the states is, in part, to describe an important feature of our federal system. That said, the two concepts can be disaggregated. To say that something is required by comity is to say, among other things, that it is a kind of courtesy generally conducive to harmonious intergovernmental relations. When we say that states are entitled to respect or autonomy as a matter of federalism or sovereignty, we typically mean something with a sharper edge; we might mean that the federal government is simply not authorized to enter a particular regulatory space or to interfere with certain state functions. And we might hold that view regardless of whether abstaining from such interference is conducive to federal-state harmony.

99 Professor Redish's well-known critique of the Court's abstention jurisprudence unquestionably does take the view that that jurisprudence is wrongheaded. See Martin $\mathrm{H}$. Redish, Abstention, Separation of Powers, and the Limits of the Judicial Function, 94 YALE L.J. 71 (1984). And Redish does take issue with the Younger Court's reliance on principles of comity and federalism to justify the requirement of abstention established in that case. But 
Indeed, it seems likely that most readers find courts' gesturing in the direction of comity in these cases entirely unremarkable. This alone should suffice to defeat the claim that comity and vertical federalism simply cannot travel together (unless we want to indulge the ambitious hypothesis that our legal culture as a whole seriously misconceives the nature of comity). Moreover, even if we thought the references to comity in these decisions were both empty and seriously confused, the question would remain why this kind of cavalier reliance on the term is endemic to decisions governing federal obligations to the states and virtually absent from cases involving states' obligations to the federal government.

\section{Comity, Supremacy, Sovereignty, ANd Membership}

In this Part, I consider three possible explanations for courts' consistent failure to characterize duties that run from the states to the federal government as exercises in comity. I begin, in Section III.A, by considering the possibility that comity's absence from these cases is simply an error and is attributable to supremacy's role in framing the relationship between the federal government and the states. Federal supremacy, the argument goes, sometimes obscures the fact that states enjoy the full status and dignity associated with sovereignty, and this causes courts to miss the point that states are fully capable of embracing norms of comity when dealing with the national government.

Section III.B explores another supremacy-based explanation for the terminological pattern in the caselaw, but it approaches the problem from the opposite direction. Thus, instead of relying on assumptions about state sovereignty to ground a critique of courts' deployment of comity, this approach treats courts' deployment of comity as a source of insight into the meaning of state sovereignty. I will suggest, specifically, that the key subset of cases ignores comity because comity cannot "travel up," and thus the cases signal that-despite the many emphatic statements to the contrary in modern cases relating to the allocation of power between the federal government and the states-U.S. states are in fact not possessed of the full status and dignity associated with sovereignty.

In Section III.C, finally, I consider the possibility that it is not supremacy and sovereignty, but membership and union, that best explain the manner in which comity floats in and out of the law of federalism. Comity, I will suggest, is absent from the cases involving state-to-federal duties because states lack the political separateness from the national government that is necessary to make comity possible.

his objection is not premised on the notion that comity has no place in the law of vertical federalism. His claim, rather, is that the Court has no business curbing the statutorily granted jurisdiction of the federal courts on the basis of its "social judgment about the relative competence of state and federal courts or about the harm caused by federal review of state policies." Id. at 86. 


\section{A. State Sovereignty Obscured}

In its most familiar incarnations, comity governs the relationships among fully autonomous sovereign nations. Thus, we need not stop to ask, in the paradigm (international) case, whether one party or another is truly a sovereign entity. That much is assumed (and/or screamingly obvious), and we can move immediately to the question of what, exactly, comity requires on the facts presented. This makes comity a relatively unattractive framework for understanding cases that announce constraints on state power, since the analysis in such cases makes it difficult to perceive U.S. states as cousins of the full-fledged sovereigns we encounter on the international stage. In the valid excuse and foreign affairs preemption cases, for example, states are directed to subordinate their policies to the dictates of the federal government. And much is made, in these cases, of the fact that state sovereignty is insufficiently potent to preserve full state autonomy. ${ }^{100}$ In this way, the cases call attention to the feature of our constitutional system-national supremacy-that renders states least like the sovereigns we encounter in the conventional comity scenario. ${ }^{101}$

Contrast this with, say, the abstention and habeas cases, which repeatedly assert that the federal government (the federal courts in particular) cannot do this-or-that because the behavior in question constitutes an affront to the sovereignty of the states. ${ }^{102}$ The substantive analysis in those cases makes it far easier for courts to gesture in the direction of comity as a governing norm, since those decisions aggressively insist that the states qualify as bona fide sovereigns.

Perhaps, then, courts' failure to rely on comity in the cases involving state-to-federal duties is simply an error brought about by supremacy's role in those decisions. When national supremacy is in the spotlight, the argument goes, courts lose sight of fundamental precepts governing our federal system: that state sovereignty coexists with supremacy, that our Constitution "specifi-

100 See, e.g., Haywood v. Drown, 556 U.S. 729, 736 (2009) ("[A]lthough States retain substantial leeway to establish the contours of their judicial systems, they lack authority to nullify a federal right or cause of action they believe is inconsistent with their local policies."); id. at 740-41 ("A State's authority to organize its courts, while considerable, remains subject to the strictures of the Constitution.").

101 As noted earlier, it is a mistake for the Court to conceptualize these jurisdictional duties in supremacy-based terms. See supra Section II.B. But the fact is that the Justices do understand the limits on state jurisdictional autonomy in those terms, and this makes the move to comity less likely.

102 See, e.g., Younger, 401 U.S. at 44 (emphasizing that federal courts must exhibit "a proper respect for state functions, a recognition of the fact that the entire country is made up of a Union of separate state governments, and a continuance of the belief that the National Government will fare best if the States and their institutions are left free to perform their separate functions in their separate ways"); id. ("[T]he National Government, anxious though it may be to vindicate and protect federal rights and federal interests, [must] always endeavor[ ] to do so in ways that will not unduly interfere with the legitimate activities of the States."). 
cally recognizes the States as sovereign entities,"103 and that the Constitution affords states "the dignity, [even if] not the full authority, of sovereignty."104 On this account, if not for the obfuscatory character of all the supremacyspeak, courts would readily characterize instances of state deference to federal interests as exercises in comity.

Note that supremacy's capacity to obscure comity's role in the cases involving state-to-federal duties is partly a byproduct of (or, at least, it is related to) the fact that supremacy seems to keep union offstage as well. For once supremacy-rather than union-is in focus, it is much easier to lose sight of the possibility that a particular legal constraint qualifies as a requirement of comity. Supremacy is, in essence, an exercise in dominion-an instance in which one sovereign flexes its constitutionally endowed muscle and another withers in its grip. Union-oriented rules, by contrast-even when they direct one sovereign to subordinate its interests to those of another-emphasize community, political kinship, and intergovernmental harmony. Thus it is unsurprising that comity-which is likewise intimately concerned with considerations of intergovernmental harmony-fades from view just as union is eclipsed by supremacy.

\section{B. State "Sovereignty" Clarified}

An alternative way of thinking about the comity-based pattern in the law of federalism would run the analysis in the opposite direction. Thus, instead of beginning with an assumption about the nature of state sovereignty and relying on it to assess the soundness of courts' deployment of the term "comity," we might presume that courts deploy the term correctly, identify and embrace the logic underlying the decisions, and see what, if anything, those decisions tell us about the nature of state sovereignty. The cases, we have seen, tell us that states can exhibit comity toward one another, and that the federal government can endorse norms of comity in its dealings with the states; but states, it would seem, cannot rely on comity to guide their behavior toward the federal government. Comity, it would seem, works horizontally and can operate downward (i.e., from a superior to a subordinate sovereign), but it cannot travel up.

It's easy enough to make sense of this schema, especially if we presume, once again, that the international law paradigm shapes our intuitions about where comity does and doesn't belong. In the horizontal federalism cases, the relevant rules apply reciprocally and are designed to foster intergovernmental harmony. Moreover, they govern the relationships among coequal sovereigns. ${ }^{105}$ In these crucial ways, they closely resemble comity-based norms that are familiar from the law of international relations.

103 Alden v. Maine, 527 U.S. 706, 713 (1999) (quoting Seminole Tribe of Fla. v. Florida, 517 U.S. 44, 71, n.15 (1996)) (internal quotation marks omitted).

104 Id. at 715.

105 See, e.g., Shelby Cnty. v. Holder, 133 S. Ct. 2612, 2623 (2013) ("[T]here is . . a fundamental principle of equal sovereignty among the States." (quoting Nw. Austin Mun. 
Where duties running from the federal government to the states are at issue, the element of political equality is of course missing, and in this sense the cases deviate significantly from the international law paradigm. But we might say, in these cases, that what we're seeing is in fact a simulation of comity-an act of grace (or even condescension) by the superior sovereign, motivated by the interests in harmony and union. The superior sovereign, on this account, treats the subordinate as if it were an equal-and so capable of relating to it in comity-based terms-when in fact the subordinate is not. From this perspective, the deference to state interests that characterizes, say, abstention doctrine or the law of habeas corpus can properly be characterized as comity, but it is comity borne of the grace of the dominant player; it is not the presumptive interactive mode for the parties.

The key move in this account is the next one: it is to observe that this kind of grace cannot be directed upwards-it is not available as an attitudinal stance for a subordinate dealing with a superior. ${ }^{106}$ The essence of the subordinate-to-superior dynamic, the argument goes, precludes both comity and its simulation. The point is not so much that it is inappropriate for a subordinate to exhibit this kind of grace to a superior (though I suppose that is true); it is, rather, that the very notion is incoherent. ${ }^{107}$

If that's right-and if states are subordinate to the federal government in just this way-then we wouldn't expect to find disputes in the caselaw as to whether a state should or must exhibit comity toward the national government under one circumstance or another. What we would expect, instead, is for cases involving states' duties to the federal government to ignore comity more or less entirely. And this is precisely what we find. As we have seen, even when supremacy is not brought to bear on a case in any traditional sense, and even when state obligations to the federal government call for intergovernmental interest-recognition, the courts overwhelmingly look to

Util. Dist. No. One v. Holder, 557 U.S. 193, 207 (2009)) (internal quotation marks omitted)); Coyle v. Smith, 221 U.S. 559, 567 (1911) (“'This Union' was and is a union of states, equal in power, dignity, and authority."). In both of these cases, the interstate equality point arises in the context of judicial review of federal action calling for unequal treatment of the states-which is to say that these are not horizontal federalism decisions. But I see no reason the point about states' equal status cannot be appropriated and applied to account for states' obligations to one another.

106 The point is nicely illustrated in Don Herzog, Poisoning THE Minds of THE Lower ORDERS 206-10 (1998) (reflecting on the downward-only character of condescension).

107 I am reminded here of exchanges I've had with my children during which one of the kids says something like "I told you to get me water," and I reply with something like: "You didn't tell me to get you water. You asked me." The point, of course, is not to correct my son's memory of what happened when he initially enlisted me in getting him a drink. (Indeed we can hope that, in the actual instance, he did, in fact, ask me for a glass of water and perhaps even adorned the request with the word "please.") The point is to signal to my son that "telling," in this sense, is not something that kids do to their parents-that it misunderstands the dynamics of the parent-child relationship for the child to presume that he might direct the parent to do something. Thus the correction is in order regardless of what the child actually said or did in the first instance. What's at stake in the exchange is what the child's terminology signals about the contours of the relevant relationship. 
supremacy to justify their conclusions and fail to use the term "comity" to describe the obligations in question. ${ }^{108}$ The basic structure of the state-federal relationship, it would seem, makes the latter characterization seem off. Or, more likely, the basic structure of that relationship prevents the characterization from even occurring to the courts.

This account is intriguing because it cuts against the grain of a prominent trend in modern federalism jurisprudence. Over the last twenty-five years or so, the Supreme Court has repeatedly called attention to states' status as bona fide sovereigns and, in particular, to the dignity with which states are endowed by virtue of that status. ${ }^{109}$ Yet still the federal courts, the Supreme Court very much included, have generally eschewed the suggestion that states are possessed of status or dignity sufficient to render comity a plausible attitudinal stance for them in their dealings with the national government. Indeed, as we have seen, the Justices would sooner conjure dubious supremacy-based justifications for the law of vertical federalism than attempt. to sell the notion that instances of state deference to federal interests might be understood as exercises in comity.

It is tempting to try to resolve this tension in the Court's orientation toward state sovereignty and dignity by embracing the approach that is made explicit in modern federalism jurisprudence, while rejecting the approach that I argue is implicit in the courts' pattern of comity-speak. After all, the Court developed the former view - that states possess the full dignity of sovereigns-self-consciously; and this conception of state sovereignty makes its way to the surface of a variety of decisions constraining the power of the national government in the name of state autonomy. ${ }^{110}$ The latter view, by contrastthat states cannot exhibit comity in their dealings with the federal government because there is a kind of deficit in their sovereignty or dignity-has never been confronted explicitly (much less endorsed) by the Court; and in fact it is discernable only after a somewhat painstaking exercise in reading between the lines. So instead of assigning to the Justices an attitude toward state sovereign dignity that might possibly be implicit in a group of decisions scattered across a range of doctrines that are not typically even thought to travel together, we might just take the Justices at their word. We might presume, that is, that the Justices (and our Constitution) endorse precisely the conception of state sovereign dignity that is advanced in the cases, and that the federal courts' nonreliance on comity in the cluster of vertical federalism decisions highlighted here tells us little about the meaning and content of state sovereignty in the context of the American federal system.

But there is something to be said, too, for reading between the lines. We might learn a great deal about the Justices' attitudes toward state sovereignty and dignity by focusing on what they communicate about those subjects when they're not looking (so to speak), instead of focusing only on what they

108 See supra Section II.B.

109 See, e.g., Shelly Cnty., 133 S. Ct. at 2623; Fed. Mar. Comm'n v. S.C. State Ports Auth., 535 U.S. 743, 760 (2002); Alden, 527 U.S. at 715.

110 See supra note 109 and accompanying text. 
say when they opine portentously on the deep rhythms of our federalism. So, yes, the cases tell us (repeatedly) that "our Constitution ... reserves to [the states] a substantial portion of the Nation's primary sovereignty, together with the dignity and essential attributes inhering in that status." 111 But they also tell us-though not in so many words-that that fragment of the nation's "primary sovereignty" is not so robust as to enable states to exhibit comity in their dealings with the federal government. We can resolve the tension in the caselaw by dismissing the comity pattern as irrelevant to questions about the meaning of state sovereignty; but this seems more like an exercise in wishing away constitutional complexity-or, perhaps, ignoring an apparently strong intuition about state sovereignty that some might prefer to disclaim-than an effort to confront and understand it.

\section{On Comity and Membership}

In this last Section, I leave behind competing visions of supremacy and sovereignty and offer a different perspective on comity's on-again, off-again role in the law of federalism. I wish to explore the possibility that the terminological pattern we see in the caselaw is driven by a conception of political membership-that the pattern is an expression of the view that comity is not a sensible way to understand a member state's deference to the political union of which it is a part.

This perspective is of interest, I think, because it resists the powerful temptation-of which we have seen considerable evidence already-to rely exclusively on the supremacy/sovereignty dichotomy to resolve contested questions about the balance of power in our federal system. And while the analysis here should not be taken as a suggestion that supremacy-oriented analysis is entirely lacking in explanatory power in this context, I do want to emphasize that, in my view, our efforts to understand American federalism are routinely hampered by an unrelenting focus on national supremacy and its relationship to state sovereignty. We can locate the foundation for some important features of our federal system elsewhere, and the ideas of membership and union are a promising place to start.

I begin, once again, with a look at our paradigm case: the relationships among nations. This time, however, I wish to focus neither on the fact that these nations unquestionably qualify as full-fledged sovereigns, nor on the fact of their equal status, but on the fact of their separation from one another-on their status as fully distinct political entities. Of course, this does not accurately describe the relationship between the national government and the fifty member-states in the American federal system. And there is reason to think this has bearing on the possibilities for comity.

Comity typically entails one political entity recognizing the official acts of some other. ${ }^{112}$ It is an exercise in one sovereign saying: " $[\mathrm{I}] \mathrm{n}$ the interest of intergovernmental harmony, we will set aside our policies (or interests or

111 Alden, 527 U.S. at 714.

112 See supra notes 6-7 and accompanying text. 
judgments or laws) and defer to yours." When governing entities and the polities they serve become intermingled with one another, this formulation becomes awkward, as the distinction between what is "ours" and what is "yours" tends to blur. This tendency is highlighted in numerous Supreme Court opinions relating to state courts' obligation to enforce and apply federal law. Thus, the Court has explained that the policy expressed in federal law "is as much the policy of [any state] as if the act had emanated from its own legislature." 113 And, it has stated, in a different context, that:

The Constitution and laws of the United States are not a body of law external to the States, acknowledged and enforced simply as a matter of comity. The Constitution is the basic law of the Nation, a law to which a State's ties are no less intimate than those of the National Government itself. The separate States and the Government of the United States are bound in the common cause of preserving the whole constitutional order. ${ }^{114}$

This last passage is telling because it connects notions of political identity and membership to the question of whether comity might serve as a governing norm. States' obligations vis-à-vis federal law, the Court tells us, are not simply "a matter of comity." 115 They are something else-something rooted in the "intimate ties" between the states and national law and in the fact that the states and the national government are "bound" to one another. ${ }^{116}$

To say that states owe the federal government a duty of comity, then, is to imagine a species of comity with an oddly self-dealing character. This selfdealing is distinct from the self-interest that would seem to lurk behind many exercises in comity. Comity's self-interested side is bound up in the idea of mutuality. Sovereign $A$ defers to Sovereign $B$ 's policy in one case with the expectation or hope that Sovereign $B$ will afford it the same courtesy in the mirror-image case, somewhere down the line. But because of the overlap in state and national polities within the American federal system, to say that a state exhibits comity toward the national government is to imagine the citizens of some state (acting through a state-level political body), showing courtesy to their own (national-level) political institutions and deferring to laws generated through a process in which they are represented. ${ }^{117}$ The notion

113 Mondou v. N.Y., New Haven \& Hartford R.R., 223 U.S. 1, 57 (1912); see Testa v. Katt, 330 U.S. 386, 393 (1947) (explaining that federal policy "is the prevailing policy in every state").

114 Idaho v. Coeur d'Alene Tribe, 521 U.S. 261, 275-76 (1997) (plurality opinion).

$115 I d$. at 275.

116 See id. at 276.

117 As noted earlier, the Court sometimes looks to comity as a means of filling a void of interstate interest-consideration that is a byproduct of the structure of political representation. See supra note 87 and accompanying text. Thus, in Austin v. New Hampshire, 420 U.S. 656 (1975), the Court indicated that state laws that adversely affect nonresidents are concerning, in part, because "nonresidents are not represented in the [enacting] State's legislative halls." Id. at 662 . Comity is thus treated as a kind of antidote to this insensitivity to outsiders. See supra text accompanying note 30 (detailing Austin's heavy reliance on comity). I don't want to press this point too hard, since it is not my view that the federal 
of deferring or being courteous to oneself-or even to a distinct expression of one's political self-is peculiar.

I don't want to overstate the point. Federal policy and the policies of individual states routinely diverge. Sometimes sharply. And it is too much to say that, just because Michiganders are part of the national polity, we simply cannot wrap our brains around the notion of Michigan deferring to national interests. ${ }^{118}$ But what we're trying to do is account for an observable pattern in the Court's federalism jurisprudence; and we can endorse the view that the dynamics of membership make comity an unattractive way to conceive of states' duties to the federal government without endorsing the stronger claim that the very idea of comity under these circumstances is wholly unintelligible.

It is appropriate at this point to ask the sort of question we confronted earlier in connection with our discussion of supremacy and sovereignty. Why, if membership figures so heavily in rendering comity an inapt description of the norms governing duties that run from the states to the federal government, does the Court turn to comity in cases involving federal deference to state interests? Shouldn't the intertwining of federal and state polities produce the same aversion to comity across vertical federalism cases? ${ }^{119}$

I don't think so, and the reason lies in the asymmetrical character of membership. Michigan is a part of the United States, but the United States is not a part of Michigan. Michigan and its citizens are represented in the fed-

government cannot or should not exhibit comity toward the states just because states and their citizens are represented in the national legislative process. But the analysis in Austin lends support to the notion that the relevance of comity to a particular intergovernmental relationship is sometimes connected to the political separateness of the parties.

118 Indeed, it is relatively easy to think of a state deferring to the nation if we focus our attention on the particular officials who might be called upon to do the deferring. There is nothing obviously strange about the notion that a judge sitting on a Michigan state court might defer to some decision from a panel of Sixth Circuit judges. But if we think about the polities that stand behind the different tribunals, the oddity of the thing begins to emerge. From a polity-based perspective, the exercise in courtesy seems more obviously reflexive.

119 We might even ask why the Court turns to comity in connection with interstate relationships, given that individual states are members of the same national political community and, so, do not stand at arm's length from one another in the manner of fully independent nation-states. See, e.g., Nevada v. Hall, 440 U.S. 410, 425-26 (1979) ("The intimate union of these states, as members of the same great political family; the deep and vital interests which bind them so closely together; should lead us, in the absence of proof to the contrary, to presume a greater degree of comity, and friendship, and kindness towards one another, than we should be authorized to presume between foreign nations." (quoting Bank of Augusta v. Earle, 38 U.S. (13 Pet.) 519, 590 (1839))). But I think we can fairly easily distinguish the ties that bind the states to the national political community from those that bind the states to one another. Thus, Michigan is a part of the United States; it is not a part of Ohio (and thank heavens for that). So notwithstanding the fact that the individual states are bound to one another in a way that is not true of, say, Canada and Japan, it is also the case that they are not politically intermingled in the way that individual states and the national government are. 
eral legislative process, but the same is not true of the United States when it comes to making Michigan law. The national government is thus removed from Michigan law in a way that is not so in the converse scenario, and so federal deference to state law and state interests lacks the reflexive character of state deference to federal law and federal interests. As a result, it is comparatively easy to ground federal deference to state law and policy in a set of ideas that presuppose political separateness. When state deference to federal law and policy is at issue, however, the distinction between the deferring polity and the deferred-to law is not nearly so sharp, and comity's attractiveness as a framing device recedes accordingly.

\section{CONCLUSION}

I have explored three hypotheses that might explain the federal courts' selective deployment of comity across the law of American federalism. The first of these-that courts' failure to rely on comity to characterize states' duties to the federal government is a kind of mistake or inadvertencestrikes me as least attractive. The sheer number of cases that contribute to the pattern is too high for claims of error or accident to carry much appeal.

More compelling, I think, is the notion that courts rely on (and ignore) comity for a reason, and that that reason is bound up in foundational features of statehood and union as practiced in our constitutional system. The fact that courts seem oblivious to the terminological pattern explored here makes it simultaneously more difficult and more intriguing to rely on the cases examined above for insight into these features of our federalism. It is more difficult because we lack the benefit of judges' explicit consideration of these questions of supremacy, sovereignty, membership, and union. Such consideration might shed light on how, exactly, courts understand comity's role in our federal system, and this, in turn, might enable us to predict more reliably when courts will require states or the federal government to obey norms of comity. It is more intriguing, however, because the decisions in question are unencumbered by the potentially obfuscatory effects of self-conscious judicial engagement with foundational questions about the nature of state sovereignty and union. The cases, in other words, might teach us something important about the contours of our federalism without quite intending to-and that, I think, renders them a particularly valuable resource. 
1344

NOTE DAME LAW REVIEW

[VOL. 90:3 